九州大学学術情報リポジトリ

Kyushu University Institutional Repository

An Interim Report of the 2000 Survey of

Entomofauna on Lombok Island, Bali Island, the Krakatau Islands, and in Ujung Kulon, Indonesia

Yukawa, Jun-ichi

Ogata, Kazuo

Yata, 0samu

Tadauchi, 0samu

他

https://doi.org/10.5109/2648

出版情報: ESAKIA. 41，pp.1-10，2001-03-31. Entomological Laboratory，Faculty of Agriculture， Kyushu University

バージョン：

権利関係 : 


\title{
An Interim Report of the 2000 Survey of Entomofauna on Lombok Island, Bali Island, the Krakatau Islands, and in Ujung Kulon, Indonesia
}

\author{
Junichi YUKAWA \\ Entomological Laboratory, Faculty of Agriculture, \\ Kyushu University, Fukuoka, 812-8581 Japan

\section{Kazuo OGATA} \\ Institute of Tropical Agriculture, Kyushu University \\ Fukuoka, 812-8581 Japan \\ Osamu YATA \\ Biosystematics Laboratory, Faculty of Social and Cultural Studies, \\ Kyushu University, Fukuoka, 810-8560 Japan

\section{Osamu TAdauchI, Satoshi KamitanI} \\ Entomological Laboratory, Faculty of Agriculture, \\ Kyushu University, Fukuoka, 812-8581 Japan
}

\section{Simbolon Helwint, Tukirin Partomihardjo}

Herbarium Bogoriense, Botanical Division, Centre for R. \& D. in Biology, Indonesian Institute of Sciences, Bogor, 16122 Indonesia

\section{Ngakan Putu OKa}

Faculty of Agriculture, Hasanuddin University,

Ujung Pandang, 90245 Indonesia

and

\section{Daisuke YAMAgUCHI}

Entomological Laboratory, Faculty of Agriculture, Kyushu University, Fukuoka, 812-8581 Japan

* Contribution from the Entomological Laboratory, Faculty of Agriculture, Kyushu University, Fukuoka (Ser. 5, No.60). 


\begin{abstract}
Entomofauna was surveyed in September-October 2000 on Lombok Island, Bali Island, the Krakatau Islands, and in Ujung Kulon, Indonesia by Japanese entomologists and Indonesian botanists. Based on tentative identifications, results of the faunistic survey were briefly presented for the following insect groups: Galling Arthropods, Ants, Bees, Auchenorrhyncha (Homoptera), Coleoptera, Diptera, and Butterflies. Kulon.

Key words: entomofauna, Indonesia, Lombok, Bali, Krakatau, Ujung
\end{abstract}

\title{
Introduction
}

A research project entitled 'Studies of the diversity and geographical ecology of insects on islands in Indonesia' started in 1999 as a cooperative study between Japanese entomologists and Indonesian botanists. This project has been planned under the concept that study of global biodiversity is an urgent necessity since species richness has been increasingly regarded to be fundamentally important for the existence of human beings. Target study areas are Indonesian islands since island is a relatively convenient unit for
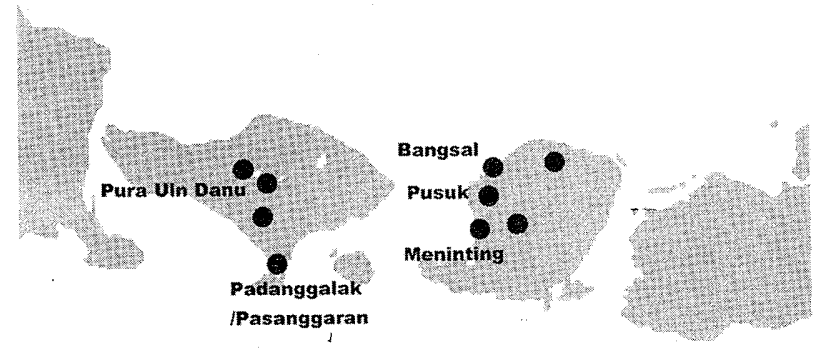

Fig. 1. Maps of the survey route on Bali and Lombok.

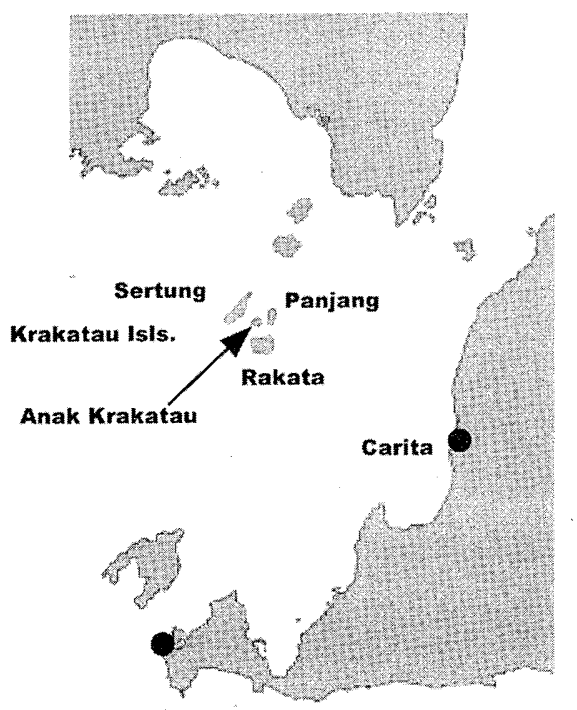

Fig. 2. Maps of the survey route on West Java. 
comparing biodiversity between localities with different geographical and ecological backgrounds.

Following the 1999 survey on Sulawesi (Yukawa et al., 1999), the research team

consisting of Japanese entomologists and Indonesian botanists visited Lombok Island, Bali Island, the Krakatau Islands, and Ujung Kulon in September-October 2000. Lombok Island is located in the East Side of the Wallace Line and Bali Island is in the West Side (Fig. 1). Comparison of entomofauna between both sides of the Wallace Line was the primary purpose to visit these islands. As mentioned in the previous report (Yukawa et al., 1999), both islands are included in an interesting area comprising several different plates (cf. Burrett et al., 1991; Michaux, 1991).

The Krakatau Islands is situated in the Sunda Strait between Java and Sumatra and now consist of 4 islets (Fig. 2). Recolonization of the Krakataus by insects has been monitored since 1883 when Krakatau Island and neighboring islands were totally sterilized by the world-famous volcanic eruption. Jacobson (1909), Dammerman (1922, 1948), Docters van Leeuwen $(1920,1922)$, etc. have surveyed the entomofauna of the Krakataus and surrounding areas from 1908 to 1930s. There were almost no surveys from 1940s to 1970 s on the Krakataus, but from 1980s field surveys were started again by Japanese entomologists (Abe, 1984; Sk.Yamane, 1983; Yukawa, 1984a; Yukawa, 1984b; Yukawa, 1984c; Yukawa \& Partomihardjo, 1997; Yukawa et al., 2000) and Australian entomologists (e.g., Thornton, 1996a; Thornton, 1996b).

Ujung Kulon is located in the westernmost part of Java (Fig. 2). Ujung Kulon, together with neighboring islands, Peucang and Panaitan, has been paid attention as a resource area from which organisms may have been colonizing the Krakatau Islands (Yukawa \& Partomihardjo, 1997).

This report outlines the 2000 field surveys on Lombok, Bali, the Krakataus, and in Ujung Kulon and presents brief notes on the faunistic studies of some arthropod groups based on tentative identifications.

The project was supported by a grant-in-aid for overseas research project in 1999 2000 from the Japanese Society for the Promotion of Sciences (JSPS).

\section{Members, Target Insects, and Specimens}

The survey team consisted of 16 Japanese and 3 Indonesian members (Table 1). Each member took charge of part of the field survey. Target organisms were Galling Arthropods, Ants, Bees, Auchenorrhyncha (Homoptera), Coleoptera, Diptera, and Butterflies. They were sampled by various methods according to different organisms; visual search on host plants, sweeping, beating, time unit sampling, light trap, and malaise trap.

All insect specimens that were collected in this survey were allowed by Dr. Siti Nuramaliati Prijono (Head, Zoological Division, Museum Zoologicum Bogoriense, LIPI, Chibinong) to bring back to Kyushu University for identification. More than half of identified specimens will be returned to the Museum in the future. The remaining specimens will be kept temporarily in the collection of Entomological Laboratory, Faculty of Agriculture, Kyushu University and will be transferred later to the collection of Kyushu University Museum.

\section{Activity}

The research activity (Table 2 ) is divided into 5 periods according to areas surveyed, Bogor and Jakarta, Lombok (Fig. 3: A-B), Bali (Fig. 3: C-D), the Krakatau Islands (Fig. 3: E), and Ujung Kulon (Fig. 3: F).

The first group of Japanese members comprising Yukawa, Ogata, Abe, and Uechi spent the first 4 days from September 24 to 27 in Bogor to get necessary permission from 

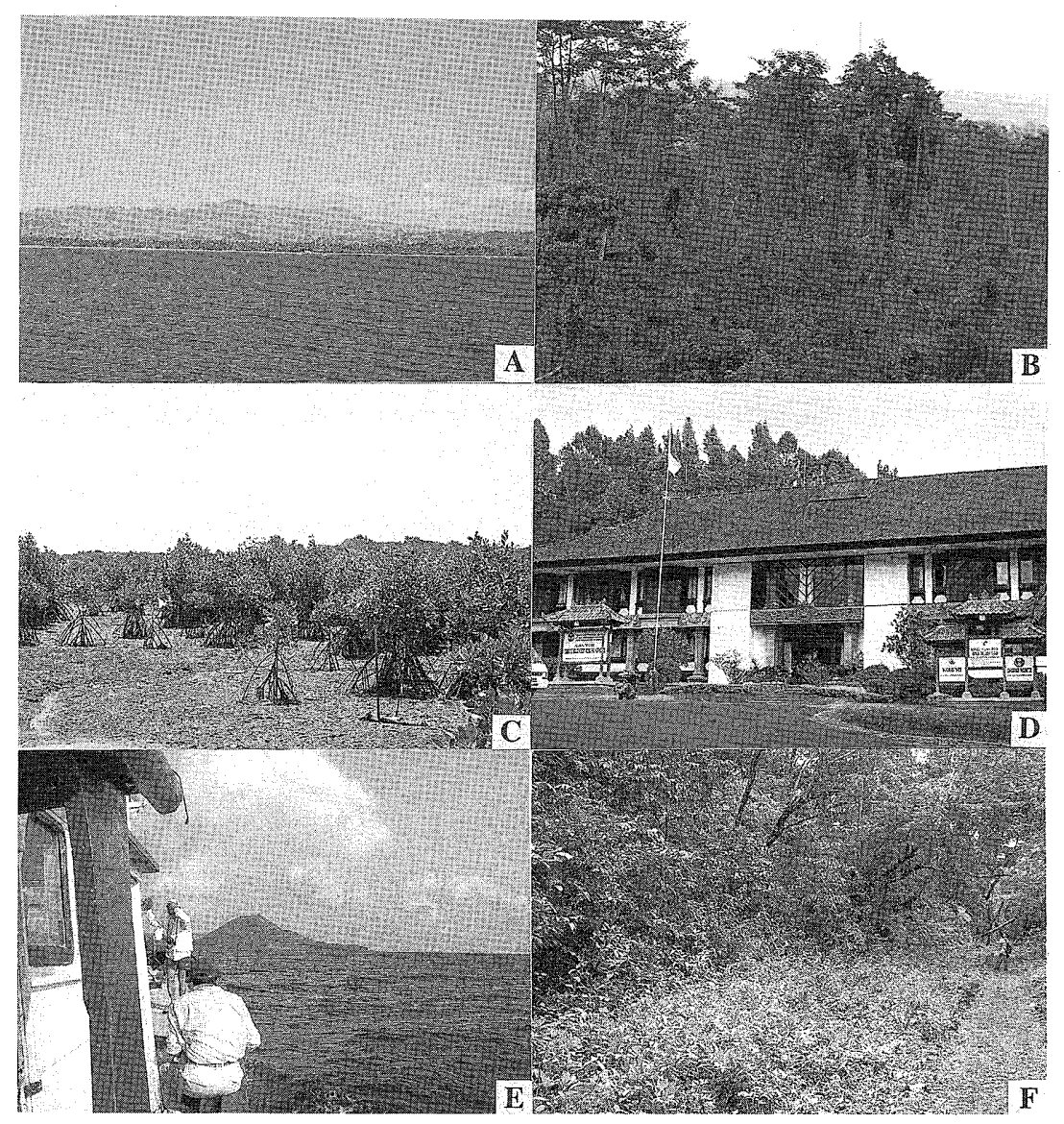

Fig. 3: A-F. Survey sites and scenary. A: Lombok Is.; B: Forest scenary in Lombok Is.; C: mangrove forest in Bali Is; D: Botanical Garden in Bedugul, Bali Is.; E: Anak Krakatau Is.; F: Forest margin in Ujung Kulon. (Photos A-D by Mrs. T. Ono)

LIPI Jakarta. During this period, they also paid a courtesy call on Dr. Arie Budiman (Director, R. \& D. Centre for Biology, LIPI, Bogor) and Dr. Irawati (Head, Botanical Division, Herbarium Bogoriense, LIPI, Bogor).

On September 28, Yukawa, Ogata, Abe, and Uechi, together with 2 Indonesian members, Simbolon and Tukirin, left Bogor for Bali, where they met 10 Japanese members arrived from Fukuoka on the same day and Ngakan from Ujung Pandang. Thus the team consisted of 14 Japanese and 3 Indonesian members. All the members visited Lombok Island on September 29. The survey on Lombok Island was performed in northern parts, including Meningting, Senaru, Sesaut, and Pusuk. The altitude ranged from 0 to $750 \mathrm{~m}$.

All members came back to Bali Island on October 2 and stayed there until October 6. During this period, they surveyed the Botanical Garden of Bali, its surrounding forests, and southwestern coastal areas. The altitude ranged from 0 to $1250 \mathrm{~m}$.

Ngakan left the team and went back to Ujung Pandang, and the others returned to Bogor on October 5 and stayed there for 3 days. During this period, Yukawa and 7 other Japanese members left Bogor for Fukuoka and 2 new members, Kamitani and Matsui 
Table 1. Members and target organisms.

\begin{tabular}{|c|c|c|}
\hline Junichi Yukawa & $\begin{array}{l}\text { Professor, Laboratory of Entomology, } \\
\text { Faculty of Agriculture, Kyushu University }\end{array}$ & $\begin{array}{l}\text { Leader } \\
\text { Galling } \\
\text { Arthropods }\end{array}$ \\
\hline Kazuo Ogata & $\begin{array}{l}\text { Associate Professor, Institute of Tropical } \\
\text { Agriculture, Kyushu University }\end{array}$ & $\begin{array}{l}\text { Leader in charge } \\
\text { Ants }\end{array}$ \\
\hline Osamu Yata & $\begin{array}{l}\text { Associate Professor, Faculty of Social and } \\
\text { Cultural Studies, Kyushu University }\end{array}$ & Butterflies \\
\hline Osamu Tadauchi & $\begin{array}{l}\text { Associate Professor, Laboratory of } \\
\text { Entomology, Faculty of Agriculture, } \\
\text { Kyushu University }\end{array}$ & Bees \\
\hline Satoshi Kamitani & $\begin{array}{l}\text { Assistant Professor, Laboratory of } \\
\text { Entomology, Faculty of Agriculture, } \\
\text { Kyushu University }\end{array}$ & Homoptera \\
\hline Daisuke Yamaguchi & $\begin{array}{l}\text { Technical Assistant, Laboratory of } \\
\text { Entomology, Faculty of Agriculture, } \\
\text { Kyushu University }\end{array}$ & Bees \\
\hline Takuji Tachi & $\begin{array}{l}\text { Post Doctoral Student, Graduate School of } \\
\text { Social and Cultural Studies, Kyushu } \\
\text { University }\end{array}$ & Diptera \\
\hline Junichiro Abe & $\begin{array}{l}\text { Graduate Student, Laboratory of } \\
\text { Entomology, Faculty of Agriculture, } \\
\text { Kyushu University }\end{array}$ & $\begin{array}{l}\text { Ants \& Galling } \\
\text { Arthropods }\end{array}$ \\
\hline Takayoshi Katsuda & $\begin{array}{l}\text { Graduate Student, Entomological Laboratory, } \\
\text { Faculty of Agriculture, Kyushu University }\end{array}$ & $\begin{array}{l}\text { Galling } \\
\text { Arthropods }\end{array}$ \\
\hline Nami Uechi & $\begin{array}{l}\text { Graduate Student, Entomological Laboratory, } \\
\text { Faculty of Agriculture, Kyushu University }\end{array}$ & $\begin{array}{l}\text { Galling } \\
\text { Arthropods }\end{array}$ \\
\hline Takeo Yamauchi & $\begin{array}{l}\text { Graduate Student, Graduate School of Social } \\
\text { and Cultural Studies, Kyushu University }\end{array}$ & Butterflies \\
\hline Sachiyo Matsui & $\begin{array}{l}\text { Graduate Student, Entomological Laboratory, } \\
\text { Faculty of Agriculture, Kyushu University }\end{array}$ & Ants \\
\hline Hiraku Yoshitake & $\begin{array}{l}\text { Graduate Student, Entomological Laboratory, } \\
\text { Faculty of Agriculture, Kyushu University }\end{array}$ & Coleoptera \\
\hline Machiko Nohara & $\begin{array}{l}\text { Undergraduate Student, Entomological } \\
\text { Laboratory, Faculty of Agriculture, Kyushu } \\
\text { University }\end{array}$ & $\begin{array}{l}\text { Galling } \\
\text { Arthropods }\end{array}$ \\
\hline Aya Saito & $\begin{array}{l}\text { Undergraduate Student, Entomological } \\
\text { Laboratory, Faculty of Agriculture, Kyushu } \\
\text { University }\end{array}$ & Homoptera \\
\hline Tayoko Ono & $\begin{array}{l}\text { Officer, Faculty of Agriculture, Kyushu } \\
\text { University }\end{array}$ & $\begin{array}{l}\text { Financial } \\
\text { management }\end{array}$ \\
\hline Simbolon Helwint & Herbarium Bogoriense, LIPI, Bogor & Ants \\
\hline $\begin{array}{l}\text { Tukirin } \\
\quad \text { Partomihardjo }\end{array}$ & Herbarium Bogoriense, LIPI, Bogor & $\begin{array}{l}\text { Galling } \\
\text { Arthropods }\end{array}$ \\
\hline Ngakan Putu Oka & Hasanuddin University, Ujung Pandang & Bees \\
\hline
\end{tabular}


arrived from Japan to replace.

Then 8 Japanese and 2 Indonesian members moved to Carita on October 8 and visited the office of PKA (Preservation and Conservation of Nature) in Labuan to get permission for the field survey on the Krakataus. They landed on Rakata Island of the Krakataus on October 9 and settled the base camp near the beach. The members also visited neighboring islands, Sertung, Panjang, and Anak Krakatau during the period from October 10 to 13.

On way to Ujung Kulon, the team visited the office of PKA on Peucang Island to get permission for the field survey in Ujung Kulon. The team landed on Cibom, Ujung Kulon on October 15 and stayed there until October 17. During these 3 days, they surveyed the areas around the base camp including Ciramea and Cidaon.

After returning from Ujung Kulon to Bogor on October 17, Ogata made a brief review of the field survey and submitted it to LIPI Bogor. Then the team followed a necessary procedure at the Zoological Museum in Cibinong for the loan of specimens that were collected in the field survey. All Japanese members left Bogor for Fukuoka on October 21.

Table 2. Itinerary and areas surveyed.

\begin{tabular}{|c|l|l|}
\hline Date (2000) & \multicolumn{1}{|c|}{ Area Surveyed } & \multicolumn{1}{|c|}{ Stay } \\
\hline September & & \\
24 (Sun) & From Fukuoka, Japan (via Jakarta) to Bogor & Bogor \\
25 (Mon) & Visit LIPI Jakarta and LIPI Bogor; Polisi; Permission & Bogor \\
26 (Tue) & request & \\
& Visit LIPI Jakarta and LIPI Bogor; Polisi and Sospol; & Bogor \\
27 (Wed) & Permission receive & Bali \\
28 (Thu) & From Bogor (via Jakarta) to Bali & Lombok \\
29 (Fri) & From Bali to Lombok & Lombok \\
$30($ Sat) & Lombok & \\
October & & Lombok \\
01 (Sun) & Lombok & Bali \\
02 (Mon) & From Lombok to Bali & Bali \\
03 (Tue) & Bali & Bali \\
04 (Wed) & Bali & Bali \\
05 (Thu) & Bali & Bogor \\
06 (Fri) & From Bali (via Jakarta) to Bogor & Bogor \\
07 (Sat) & Bogor & Bogor \\
08 (Sun) & Bogor & Carita \\
09 (Mon) & From Bogor to Carita & Rakata \\
10 (Tue) & From Carita to Krakataus & Rakata \\
11 (Wed) & Krakataus & Rakata \\
12 (Thu) & Krakataus & Rakata \\
13 (Fri) & Krakataus & Carita \\
14 (Sat) & From Krakatau to Carita & Ujung Kulon \\
15 (Sun) & From Carita to Ujung Kulon & Ujung Kulon \\
16 (Mon) & Ujung Kulon & Ujung Kulon \\
17 (Tue) & Ujung Kulon & Bogor \\
18 (Wed) & From Ujung Kulon (via Jakarta) to Bogor & Bogor \\
19 (Thu) & Bogor & Bogor \\
20 (Fri) & Bogor & Bogor \\
21 (Sat) & Bogor & [Air] \\
22 (Sun) & From Bogor to Jakarta / From Jakarta & \\
& Arrive in Fukuoka, Japan & \\
\hline
\end{tabular}




\section{Results}

\section{Galling Arthropods}

Insect and mite galls were surveyed by visual searching on plants by Yukawa, Tukirin, Uechi, Katsuda, Nohara, and Abe. Gall-bearing plants were identified by Tukirin at the species or generic level by comparing them with the herbarium collection in Bogor. A total of 165 or more sorts of gall were found throughout the field survey. At least 66 sorts of gall were collected on Lombok and 46 on Bali. Among them, only 8 sorts $(12.12 \%$ from Bali side) were common on both islands.

On the Krakataus, at least 26 sorts of gall were collected from 20 plant species. Among them, 2 were recorded, for the first time, from the Krakataus. In Ujung Kulon, at least 37 sorts of gall were found on about 32 plant species, but none of them were found on the Krakataus.

Galls caused by cecidomyiids were most abundant and followed by those of eriophyoid mites, psyllids, thrips, moths, and tephritids. Such a relative abundance among gallers was quite similar to that of Indonesian gallers recorded by Docters van Leeuwen-Reijnvaan \& Docters van Leeuwen (1926). Most galls were produced on the leaves or stems of host plants.

\section{Ants}

Ogata, Abe, Matsui, and Simbolon surveyed ants. Like in the 1999 survey on Sulawesi Island, the main sampling method was a time unit sampling. They collected as many ant species as possible, within a 15 -minnute-unit time, from the ground, tree trunks, plant leaves, under stones, and rotten woods by visual search using a sifter and a pan. A total of 70 or more species in 41 genera of 7 subfamilies were collected by 150 times of the TUS sampling. At least 60 species and 40 species were obtained from Lombok and Bali, respectively, and 30 or more species were collected from the Krakatau Islands and Ujung Kulon, respectively. The commonest ant genera were Hypoponera, Odontomachus, Pheidole, Dolichoderus, and Anoplolepis. One of the typical tropical Asian ants, Oecophylla smargdina, was also common, but was not found on Sertung of the Krakataus and in Cibom of Ujung Kulon.

\section{Bees}

Tadauchi, Yamaguchi, and Ngakan collected bees by visual search mainly on flowers. On Lombok, 35 species belonging to 14 genera of 3 families were collected on flowers of 14 plant species. Individual number was remarkably abundant in the genera Apis, Xylocopa, and Lasioglossum. Megachile and Xylocopa were most abundant in species number, including 7 and 5 species, respectively. Trigona was poor in species and individual numbers. Ten out of 14 genera that were collected on Lombok were found also in Bali, and Sphecodes, Lipotriches, Coelyoxysand, and Nomada were collected on Lombok alone. On Bali, a total of 27 species belonging to 12 genera of 3 families were collected on flowers of 24 plant species. Individual number was most abundant in the genera Apis, Megachile, Ceratina, and Xylocopa. Megachile (6 spp.) and Lasioglossum (5 spp.) were abundant in species number. Nomia and Pithitis were collected more abundantly in low lands, whilst Apis and Lasioglossum were only in mountainous regions. Bee fauna was relatively rich in low lands and beach areas, whilst it was very poor in mountainous regions.

\section{Auchenorrhyncha (Homoptera)}

Auchenorrhyncha including 4 superfamilies, Membracoidea (Cicadelloidea), Fulgoroidea, Cercopoidea, and Cicadoidea, was surveyed by Saito on Bali and Lombok and by Kamitani on the Krakataus and in Ujung Kulon. In order to study the biodiversity, the insects were sampled by sweeping and the numbers of species and 
individuals were counted at every 60 sweepings. They were also collected at a light trap on the Krakataus and in Ujung Kulon. At least 450 specimens of Auchenorrhyncha were collected from Lombok and 350 from Bali. The species diversity was relatively high at forest margins in mountains and highlands. In beach vegetation and mangroves on Lombok and Bali, auchenorrhynchan insects were few in species number.

Thirty-two species of 9 auchenorrhynchan families were collected on the Krakataus. The species richness was most abundant on Rakata where 28 species ( 2.7 spp. / 60 sws.) were found. Some dominant species like Paivanana sp. were observed to feed on grasses of the family Poaceae. In Ujung Kulon, about 55 species of 12 auchenorrhynchan families were collected. At forest margins, including a trail to the lighthouse, 50 species (5.2 spp. / 60 sws.) were collected, whilst 24 species $(2.3$ spp. $/ 60$ sws.) were found inside the forests. Only several species, Xestocephalus sp. etc., were common to the Krakataus.

\section{Coleoptera}

Mainly Yoshitake collected beetles by sweeping, beating, visual searching, and at a light trap. At least 600 specimens of Coleoptera were collected. Curculionidae and Chrysomelidae were most abundant. Faunistic difference between Bali and Lombok was recognized for celeuthetine weevils of the subfamily Othorhynchinae. On the Krakataus and in Ujung Kulon, at least 1000 individuals of Coleoptera were collected. On Rakata, fruit traps and a light trap attracted many individuals of a lucanid beetle, Dorcus taurus. This may be the first collection record of that species from the Krakataus. In Ujung Kulon, Curculionoidea was most abundant in Coleoptera, of which such wood feeders as anthribids, zygopines and cryptorhynchines were occupied a greater part of the specimens obtained in the survey.

\section{Diptera}

Dipteran insects were collected by Tachi with a malaise trap, sweeping, and visual search. The malaise trap was set up in the Botanical Garden of Bali, on Rakata Island of the Krakataus, and in Cibom, Ujung Kulon. At least 600 specimens belonging to 18 families were collected. Most of the time was devoted to the collection of tachinids and dolichopodids, resulting in the catches of at least 40 and 25 species, respectively.

Special attention was paid to daily activities of tachinid flies at the Botanical Garden of Bali. They were quite active particularly during the morning around the forest margins and gaps near water streams, but disappeared after 10:00 a.m.

\section{Butterflies}

Yata and Yamauchi collected butterflies by a screen net between 9:30 a.m. and 3:30 p.m. in various localities from lowland ( 0 to $260 \mathrm{~m}$ alt.) up to mountain (540 to $750 \mathrm{~m}$ alt.). At least 250 individuals of 70 species were collected on Lombok and 240 individuals of 64 species belonging to 5 families on Bali. The numbers of both species and individuals were almost same on the 2 islands, and they were more abundant in mountain regions than in lowlands. A pierid genus Eurema and nymphalid genera Ypthima and Neptis exhibited clear altitudinal differences in the species component, some species having been found only in mountain regions (higher than $750 \mathrm{~m}$ alt.) whilst others in lowlands alone. Eurema andersoni (1 male) was collected, for the first time, from Lombok. This species and Eurema lombokiana that has been regarded as a very rare species were found only in a mountain forest of northern Lombok.

About 100 specimens consisting of at least 20 species and 250 specimens of at least 40 species were collected from the Krakatau Islands and Ujung Kulon, respectively. 


\section{Acknowledgements}

The authors wish to express their hearty thanks to Indonesian Institute of Science (LIPI) for allowing them to survey at various localities in Indonesia. The authors would like to extend their sincere gratitude to Dr. Arie Budiman (Director, R. \& D. Center for Biology, LIPI, Bogor) and Dr. Irawati (Head, Botanical Division, Herbarium Bogoriense, LIPI, Bogor) for their kind help and advise in various ways. The authors are very grateful to Dr. Siti Nuramaliati Prijono (Head, Zoological Division, Museum Zoologicum Bogoriense, LIPI, Chibinong) and Dr. Sih Kahono (Zoological Division, Museum Zoologicum Bogoriense, LIPI, Chibinong) for their good office in arranging the loan of specimens. Mr. Hiroo Uehara (JICA) and Dr. Toshinao Okayama (JICA) generously allowed the team to use their facilities, for which the authors appreciate their kindness very much. The authors' hearty thanks are also due to the following persons from Kyushu University for their help in the field survey and in preparing specimens and data: Mrs. Tayoko Ono (Chief Officer), Dr. Takuji Tachi (Post Graduate Student), Mr. Junichiro Abe (Graduate Student), Mr. Takayoshi Katsuda (Graduate Student), Miss Nami Uechi (Graduate Student), Mr. Takeo Yamauchi (Graduate Student), Miss Sachiyo Matsui (Graduate Student), Mr. Hiraku Yoshitake (Graduate Student), Miss Machiko Nohara (Undergraduate Student), and Miss Aya Saito (Undergraduate Student). Some of dipteran specimens were identified by Dr. Yang Ding (Department of Entomology, China Agricultural University), Mr. Hiroto Nakayama (Graduate Student, Kyushu University), Dr. Masahiro Sueyoshi (Post Graduate Student, Kyushu University), Dr. Satoshi Shinonaga (Department of Medical Zoology, Tokyo Medical and Dental University), and Dr. Hiromu Kurahashi (Department of Medical Entomology, National Institute of Infectious Diseases), to whom the authors are deeply indebted.

\section{References}

Abe, T. 1984. Colonization of the Krakatau Islands by termites (Insecta: Isoptera). Physiol. Ecol. Japan, 21: 63-88.

Burrett, C., N. Duhig, R. Berry \& R. Varne 1991. Asian and south-western Pacific continental terranes derived from Gondowana, and their biogeographic significance. Australian Syst. Bot., 4: 13-24.

Dammerman, K. W. 1922. The fauna of Krakatau, Verlaten Island and Sebesy. Treubia, 3: $61-112$.

Dammerman, K. W. 1948. The fauna of Krakatau 1883-1933. Verhandl. Koninkl. Ned. Akad. Wetenschap. Afdel. Natuurk. 2, 44: 1-594.

Docters van Leeuwen, W. M. 1920. The galls of Krakatau and Verlaten Eiland (Desert Island) in 1919. Ann. Jard. Botan. Buitenzorg, 31: 83-92.

Docters van Leeuwen, W. M. 1922. The galls of the islands of the Krakatau-group and of the island of Sebesy. Bull. Jard. Botan. Buitenzorg 3, 4: 288-314.

Docters van Leeuwen-Reijnvaan, J \& Docters van Leeuwen, W. M. 1926. The Zoocecidia of the Netherlands East Indies. Batavia-Drukkerij de Unie, $601 \mathrm{pp}$.

Jacobson, E. R. 1909. De nieuwe fauna van Krakatau. Jaar. Top. Dienst. Ned. Ind., 1908: 192.

Michaux, B. 1991. Distribution patterns and tectonic development in Indonesia. Australian Syst. Bot., 4: 25-36.

Thornton, I. W. B. 1996a. Krakatau, The Destruction and Reassembly of an Island Ecosystem. Harvard Univ. Press, Cambridge, Massachusetts, and London, 345pp.

Thornton, I. W. B. 1996b. The origins and development of island biotas as illustrated by Krakatau. pp. 67-90, In Keast, A. \& S.G. Miller (eds.). The Origin and Evolution of Pacific Island Biotas. New Guinea to Eastern Polynesia: Patterns and Processes. SPB Academic Publishing, The Netherlands. 
Yamane, Sk. 1983. The aculeate fauna of the Krakatau Islands (Insecta, Hymenoptera). Rep. Fac. Sci, Kagoshima Univ. (Earth Sci. \& Biol.), (16): 75-107.

Yukawa, J. 1984a. An outbreak of Crypticerya jacobsoni (Green) (Homoptera: Margarodidae) on Rakata Besar of the Krakatau Islands in Indonesia. Appl. Ent. Zool., 19: 175-180.

Yukawa, J. 1984b. Fruit flies of the genus Dacus (Diptera: Tephritidae) on the Krakatau Islands in Indonesia, with special reference to an outbreak of Dacus albistrigatus De Meijere. Jpn. J. Ecol., 34: 281-288.

Yukawa, J. 1984c. Geographical ecology of the butterfly fauna of the Krakatau Islands, Indonesia. Tyô to $G a, 35:$ 47-74.

Yukawa, J., K. Ogata, S. Kamitani, T. Ueno, T. Partomihardjo, S. Kahono \& P. O. Ngakan 1999. A preliminary report of the field survey in 1999 on Sulawesi Island, Indonesia. Bull. Inst. Trop. Agr., Kyushu Univ., 22: 51-57.

Yukawa, J. \& T. Partomihardjo 1997. Insect and mite galls collected from Peucang, Panaitan, and the Krakatau Islands, Indonesia. Tropics, 7: 141-152.

Yukawa, J., T. Partomihardjo, O. Yata \& T. Hirowatari 2000. An assessment of the role of Sebesi Island as a stepping-stone for the colonisation of the Krakatau Islands by butterflies. Esakia, (40): 1-10. 